\title{
Bio-Inspired Green Nanoparticles: Synthesis, Mechanism, and Antibacterial Application
}

\author{
Palaniyandi Velusamy, Govindarajan Venkat Kumar, Venkadapathi Jeyanthi, \\ Jayabrata Das and Raman Pachaiappan \\ Department of Biotechnology, School of Bioengineering, SRM University, Kattankulathur - 603 203, Tamil Nadu, India
}

(Received July 28, 2015; Revised August 7, 2015; Accepted August 18, 2015)

\begin{abstract}
In the recent years, noble nanoparticles have attracted and emerged in the field of biology, medicine and electronics due to their incredible applications. There were several methods have been used for synthesis of nanoparticles such as toxic chemicals and high energy physical procedures. To overcome these, biological method has been used for the synthesis of various metal nanoparticles. Among the nanoparticles, silver nanoparticles (AgNPs) have received much attention in various fields, such as antimicrobial activity, therapeutics, bio-molecular detection, silver nanocoated medical devices and optical receptor. Moreover, the biological approach, in particular the usage of natural organisms has offered a reliable, simple, nontoxic and environmental friendly method. Hence, the current article is focused on the biological synthesis of silver nanoparticles and their application in the biomedical field.
\end{abstract}

Key words: Biological synthesis, Metal nanoparticles, Antibacterial activity, Protein degradation, DNA damage

\section{INTRODUCTION}

The study of nanomaterial has been emerging dramatically throughout the world in the $21^{\text {st }}$ century due to their incredible applications in all spheres of human life (1). It has opened several arms in the development of new nanomaterials and examining their properties by tuning the particle size, shape and distribution (2,3). Metal nanoparticles have been extensively studied due to their specific characteristics such as catalytic activity, optical properties, electronic properties, antimicrobial properties and magnetic properties (4). Traditionally UV irradiation, aerosol technologies, lithography, laser ablation, ultrasonic fields, and photochemical reduction techniques have been used successfully to produce various metal nanoparticles such as gold, silver, platinum and palladium. However, considering the fast growth in the usage of nanomaterials in diverse fields, there is an urgent need to develop clean, nontoxic, simple and

Correspondence to: Palaniyandi Velusamy, Department of Biotechnology, School of Bioengineering, SRM University, SRM Nagar, Kattankulathur - 603 203, Chennai, India

Email: velusamy.p@ktr.srmuniv.ac.in

This is an Open-Access article distributed under the terms of the Creative Commons Attribution Non-Commercial License (http:// creativecommons.org/licenses/by-nc/3.0) which permits unrestricted non-commercial use, distribution, and reproduction in any medium, provided the original work is properly cited. eco-friendly procedures for their synthesis.

Synthesis of noble metal nanoparticles, in particular silver nanoparticles (AgNPs) synthesis using natural organism has become a major research area in the field of nanotechnology. This may due to their simplicity of procedures, stability of nanoparticles, and their potential applications in chemical sensing, biological imaging, antimicrobial, gene silencing, drug delivery (5). Recently, several studies have reported natural polymers such as chitosan, starch and tannic acid as reducing agents for the synthesis of silver and gold nanoparticles $(6,7)$. A vast array of biological resources including plants, algae, fungi, yeast, bacteria, and viruses has been studied so far for the intra and extracellular synthesis of silver, gold, platinum and titanium nanoparticles in different sizes and shapes were tabulated in Table 1. The major drawback of metal nanoparticles synthesis using plant extracts as reducing and stabilizing agent. This differs due to significant variation of biochemical compositions present in the plant extract of the same species differ from other part of the world. Therefore, identifying the biomolecules responsible for mediating the nanoparticles synthesis is a problem to overcome (8).

\section{BACTERIA MEDIATED SYNTHESIS OF NANOPARTICLES}

Soil is an extensively explored ecological niche for sources 
Table 1. Biological synthesis of metal nanoparticles using various organisms

\begin{tabular}{|c|c|c|c|c|}
\hline Sources & Type of nanoparticles & Location & Size $(\mathrm{nm})$ & References \\
\hline \multicolumn{5}{|l|}{ A. Bacteria } \\
\hline Pseudomonas aeruginosa & $\mathrm{Au}$ & Extracellular & $15 \sim 30$ & 9 \\
\hline Pseudomonas stutzeri & $\mathrm{Ag}$ & Intracellular & 200 & 11 \\
\hline Bacillus subtilis & $\mathrm{Ag} \& \mathrm{Au}$ & Intra \& Extracellular & $5 \sim 10$ & 12 \\
\hline Shewanella oneidensis & $\mathrm{U}$ & Extracellular & 150 & 17 \\
\hline Lactobacillus sp. & $\mathrm{Ag} \& \mathrm{Au}$ & Intracellular & 60 & 46 \\
\hline Escherichia coli & $\mathrm{CdS}$ & Intracellular & $2 \sim 5$ & 24 \\
\hline Clostridium thermoaceticum & $\mathrm{CdS}$ & Intra \& Extracellular & $2 \sim 5$ & 47,48 \\
\hline Rhodopseudomonas capsulate & $\mathrm{Au}$ & Extracellular & $10 \sim 20$ & 49 \\
\hline Escherichia coli $\mathrm{DH} 5 \alpha$ & $\mathrm{Au}$ & Intracellular & $25 \sim 33$ & 50 \\
\hline Thermomonospora spp. & $\mathrm{Au}$ & Extracellular & 8 & 51 \\
\hline Streptomyces albidoflavus & $\mathrm{Ag}$ & Intracellular & $10 \sim 14$ & 52 \\
\hline Klebsiella pneumonia & $\mathrm{Ag}$ & Extracellular & $5 \sim 32$ & 53 \\
\hline \multicolumn{5}{|l|}{ B. Virus } \\
\hline \multirow{2}{*}{$\begin{array}{l}\text { Tobacco mosaic virus (TMV) } \\
\text { M13 bacteriophage }\end{array}$} & \multirow{2}{*}{$\begin{array}{l}\mathrm{SiO}_{2}, \mathrm{CdS}, \mathrm{PbS}, \mathrm{Fe}_{2} \mathrm{O}_{3} \\
\mathrm{ZnS} \text { and } \mathrm{CdS}\end{array}$} & Intra \& Extracellular & $45 \sim 80$ & 22 \\
\hline & & Intra \& Extracellular & $50 \sim 100$ & 23 \\
\hline \multicolumn{5}{|l|}{ C. Fungi } \\
\hline Phoma sp. 3.2883 & $\mathrm{Ag}$ & Extracellular & $71 \sim 74$ & 54 \\
\hline Fusarium oxysporum & $\mathrm{Ag}$ & Extracellular & $5 \sim 15$ & 55 \\
\hline Verticillium & $\mathrm{Ag}$ & Intracellular & 25 & 56 \\
\hline Aspergillus fumigates & $\mathrm{Ag}$ & Extracellular & $5 \sim 25$ & 57 \\
\hline Trichoderma asperellum & $\mathrm{Ag}$ & Extracellular & $13 \sim 18$ & 58 \\
\hline Phaenerochaete chrysosporium & $\mathrm{Ag}$ & Extracellular & $50 \sim 200$ & 56 \\
\hline Fusarium oxysporum & Magnetite & Extracellular & $20 \sim 50$ & 59 \\
\hline \multicolumn{5}{|l|}{ D. Yeast } \\
\hline Pichia jadinii & $\mathrm{Au}$ & Intracellular & 100 & 21 \\
\hline Torulopsis & $\mathrm{CdS}$ & Intracellular & $2 \sim 5$ & 24 \\
\hline Candida glabrata & $\mathrm{CdS}$ & Intracellular & 200 & 60 \\
\hline Schizosaccharomyces pombe & $\mathrm{CdS}$ & Intracellular & $1 \sim 1.5$ & 60 \\
\hline \multicolumn{5}{|l|}{ E. Algae } \\
\hline Scencedesmus sp. & $\mathrm{Ag}$ & Extracellular & $15 \sim 20$ & 61 \\
\hline Chlorella vulgaris & $\mathrm{Au}$ & Extracellular & $9 \sim 20$ & 62 \\
\hline \multicolumn{5}{|l|}{ F. Plant } \\
\hline Alfalfa sprouts & $\mathrm{Ag}$ & Intracellular & $2 \sim 20$ & 26 \\
\hline Cinnamomum camphora & $\mathrm{Ag}$ and $\mathrm{Au}$ & Extracellular & $55 \sim 80$ & 45 \\
\hline Azadirachta indica (Neem) & $\mathrm{Ag} / \mathrm{Au}$ & Extracellular & $50 \sim 100$ & 63,64 \\
\hline Geranium leaves plant extract & $\mathrm{Ag}$ & Extracellular & $16 \sim 40$ & 65 \\
\hline Avena sativa (Oat) & $\mathrm{Au}$ & Extracellular & $5 \sim 85$ & 66 \\
\hline Aloe vera & $\mathrm{Au}$ & Extracellular & $50 \sim 350$ & 67 \\
\hline \multicolumn{5}{|l|}{ G. Human cell lines } \\
\hline $\mathrm{SiHa}$ & $\mathrm{Au}$ & Intracellular & $20 \sim 100$ & 33 \\
\hline HeLa & $\mathrm{Au}$ & Intracellular & $20 \sim 100$ & 33,34 \\
\hline SKNSH & $\mathrm{Au}$ & Intracellular & $20 \sim 100$ & 33 \\
\hline HEK-293 & $\mathrm{Au}$ & Intracellular & $20 \sim 100$ & 33,34 \\
\hline
\end{tabular}

of microorganisms that are involved in various interactions. Among these, Metal-microbe interactions have important roles with fascinating applications such as bioremediation, biomineralization, bioleaching and microbial corrosion. However, recently that microorganisms have been explored as potential biofactory for synthesis of metallic nanoparticles such as cadmium, gold and silver $(9,10)$. Among the microbes, the use of bacteria, like in this study, is rapidly gaining importance due to its growing success, ease of handling and genetic modification. Klaus et al. demonstrated 
that the Pseudomonas stutzeri AG259, isolated from a silver mine, produced silver nanoparticles of well-defined size and distinct morphology within the periplasmic space of the bacteria (11). In recent study various bacterial strains such as Bacillus amyloliquefaciens, Acinetobacter calcoaceticus, Escherichia coli and Bacillus megaterium could effectively induce the synthesis of silver nanoparticles $(12,13)$. Biosynthetic methods can be categorized into intracellular and extracellular synthesis according to the place where nanoparticles are formed. Of which, the extracellular synthesis of nanoparticles is still continually emerging in order to understand the mechanisms of synthesis, easy downstream processing and rapid scale-up processing. For these reasons, a bacterial system could prove to be a potential source for the extracellular synthesis of metal nanoparticles instead of physical and chemical procedures.

\section{VIRUS MEDIATED SYNTHESIS OF NANOPARTICLES}

Viruses are unicellular organisms that hijack the replication machinery of the host cell and suspend most endogenous cellular activity. Their structure consists of nucleic acid, either DNA or RNA, which is surrounded by a protein shell that may or may not contain a lipid envelope. Viral genomes can be non-segmented, consisting of a single nucleic acid molecule, or segmented, consisting of more than one nucleic acid molecule. The nucleic acid molecules of a virus can be contained within a single virus or separated into multiple viruses. Viruses do not express their own ribosomal RNA. Viruses hold great promise in assembling and interconnecting novel nanosized components, allowing developing organized nanoparticle assemblies. Due to their size, monodispersity, and variety of chemical groups available for modification, they make a good scaffold for molecular assembly into nanoscale devices. Virus based nanocomposites are useful as an engineering material for the construction of smart nano-objects because of their ability to associate into desired structures including a number of morphologies. Viruses exhibit the characteristics of an ideal template for the formation of nano-conjugates with noble metal nanoparticles.

These bioinspired systems form monodispersed units that are highly amenable through genetic and chemical modifications. As nanoscale assemblies, viruses have sophisticated yet highly ordered structural features, which, in many cases, have been carefully characterized by modern structural biological methods. For many years animal viruses have been developed for material science, gene delivery and gene therapy purposes. More recently, other pathogens such as plant viruses, bacteriophages and viruses are increasingly being used for nanobiotechnology purposes because of their relative structural and chemical stability, ease of production, and lack of toxicity and pathogenicity in ani- mals or humans (14). Biological scaffolds (viruses) hold great promise in assembling and interconnecting novel nanosized components, allowing such organized assemblies to interface with well-developed technologies such as lithography as nanotechnology develops (15). The cowpea mosaic virus (CPMV), for example, due to its size, monodispersity, and variety of chemical groups available for modification, makes a good scaffold for molecular assembly into nanoscale devices. The tobacco mosaic virus (TMV) was also used as bio-template, which has the shape of a linear tube, for assembly of various kinds of nanoparticles inside and outside the tubes. One can assemble gold nanoparticles onto the surfaces of polypeptide nanotubes while controlling their assembly position on the biomolecules using the specific affinities of the polypeptide sequences (16).

\section{FUNGI MEDIATED SYNTHESIS OF NANOPARTICLES}

Cell mass or extracellular components from fungi, such as Fusarium oxysporum, Aspergillus flavus, Aspergillus clavatus, and Penicillium brevicompactum $(17,18)$ have been utilized for the reduction of silver ions to AgNPs. Filamentous fungi possess some distinctive advantages over bacteria due to high metals tolerance, wall binding capacity, and intracellular metal uptake capabilities (19). Previously, Vigneshwaran et al. (20) also showed that the use of Aspergillus flavus resulted in the accumulation of silver nanoparticles on the surface of its cell wall when incubated with silver nitrate solution for $72 \mathrm{hr}$. The average particle size was found to be $8.92 \mathrm{~nm}$. The intracellular synthesis of gold nanoparticles produced by $V$. luteoalbum (21) showed morphologies of spherical, hexagonal and rods in the size range of $8.92 \sim 25 \mathrm{~nm}$. Fungi are more advantageous compared to other microorganisms in many ways. Fungal mycelial mesh can withstand flow, pressure, agitation and other conditions in bioreactors or other chambers compared to plant materials and bacteria. These are fastidious to grow, easy to handle and easy for fabrication. The extracellular secretions of reductive proteins are more and can be easily handled in downstream processing. Since the nanoparticles precipitated outside the cell is devoid of unnecessary cellular components, it can be directly used in various applications.

\section{YEAST MEDIATED SYNTHESIS OF NANOPARTICLES}

Among the eukaryotic microorganism, yeast has been exploited mainly for the synthesis of semiconductors. Candida glubrata produced intracellularly monodispersed spherically shaped peptide bound CdS quantum crystallites of $20 \AA$ by neutralizing the toxicity of metal ions by forming metal-thiolate complex with phytochelatins (22) and Schizosaccharomyces pombe also produced wurtzite-typed hexag- 
onal lattice structured $\mathrm{CdS}$ nanoparticles in mid-log phase in the range of $1 \sim 1.5 \mathrm{~nm}$ (23). Kowshik et al. (24) first reported the synthesis of fcc structured CdS nanocrystallites exhibiting quantum semiconductor properties using yeast, Torulopsis sp. which intracellularly produced in the vacuoles with a dimension of $2 \sim 5 \mathrm{~nm}$ in spherical morphology when incubated with $\mathrm{Pb} 2+$ exhibiting $\lambda$ max of $330 \mathrm{~nm}$ in UV-Vis spectrophotometer. These nanoparticles were used to fabricate diode heterojunction with poly (p-phenylenevinylene). In addition, baker's yeast, $S$. cerevisiae was also reported to biosorb and reduces $\mathrm{Au}^{+}$to elemental gold in the peptidoglycan layer of the cell wall in situ by the aldehyde group present in reducing sugars (25). Similarly, Pichia jadinii intracellularly formed gold nanoparticles of spherical, triangular and hexagonal morphologies throughout the cell mainly in the cytoplasm, of size $100 \mathrm{~nm}$ in $24 \mathrm{hr}$ (26).

\section{ALGAE MEDIATED SYNTHESIS OF NANOPARTICLES}

Algae are eukaryotic aquatic oxygenic photoautotrophs, which produce its food through photosynthesis using sunlight producing oxygen as their by-products. Their photosynthesis machinery has been evolved from cyanobacteria via endosymbiosis. They are predominant primary producers in many aquatic environments. Among various algae, Chlorella sp. was found to accumulate various heavy metals such as cadmium, uranium, copper, and nickel. Chlorella vulgaris is a single-celled green algae belonging to phylum Chlorophyta, and the extracts of $C$. vulgaris showed anti-tumor properties (27). The dried algal cells were found to have a strong binding ability towards tetrachloroaurate (III) ions to form algal-bound gold, which was subsequently reduced to form $\mathrm{Au}^{(0)}$. Nearly $88 \%$ of algal-bound gold attained metallic state and the crystals of gold were accumulated in the interior and exterior of cell surfaces with tetrahedral, decahedral and icosahedra structures. Though chemical synthesis produces nanoparticles more rapidly with well-controlled shape, size and dispersity, the use of toxic and expensive chemicals as reducing and capping agents restricts its use in biomedical applications.

In that case, optimizing the conditions like $\mathrm{pH}$, temperature and metal ions (solute) concentration for expediting the biological synthesis of nanoparticles with narrow size and shape is mandatory. To date, only very few reports have been documented on the optimization in biological processes. A 28-kDa "gold shape-directing protein (GSP)" present in the extract of green algae, C. vulgaris, was used in the bioreduction and in the synthesis of size/shape controlled distinctive triangular and hexagonal gold nanoparticles. With an increase in the concentration of GSP, gold plates with lateral sizes up to micrometers were produced (28). The study of heavy metal biosorption by various algae showed that brown algae are superior compared to other autotrophs and algae (29).

\section{PLANTS MEDIATED SYNTHESIS OF NANOPARTICLES}

Indeed, a number of bacteria, fungi and yeast have been well-known for the synthesis of non-toxic noble nanoparticles. However the microbial mediated synthesis of nanoparticles is not industrially feasible as it requires expensive medium and maintenance of highly aseptic conditions. Hence, exploration of the plant systems as the potential bio-factories has gained heightened interest in the biological synthesis of nanoparticles. Hence, exploration into plant systems has been considered to be a potential bioreactor for synthesis of metal nanoparticles without using toxic chemicals.

Recently, we have reported that the various plant materials such as Rosmarinus officinalis (30), Sesbania grandiflora (31), Tribulus terrestris (32), used for biological synthesis of silver and gold nanoparticles. In continuation of the efforts for synthesizing gold nanoparticles by green route, here we present a report on the facile, rapid, and single pot aqueous biosynthesis of these nanoparticles using leaf extract of $S$. grandiflora L. (belonging to the family Fabaceae), which is commonly known as agati. The literature survey revealed that they are rich in various active ingredients such as water soluble antioxidant polyphenols, flavonoids etc, and research is still underway.

\section{HUMAN CELL LINE MEDIATED SYNTHESIS OF NANOPARTICLES}

Human cells are heterotrophic in nutrition. They need to be provided with energy for their survival. Human cancer cells and non-cancerous cells intracellularly produced some metal nanoparticles in vitro conditions that mimic their natural cellular environment. With an incubation of $1 \mathrm{mM}$ of tetrachloroaurate solution, human cancer cells like SiHa (malignant cervical epithelial cells), SKNSH (human neuroblastoma) and HeLa (malignant cervical epithelial cells), and non-cancer cells like HEK-293 (non-malignant human embryonic kidney cells) synthesized gold nanoparticles in the size range of $20 \sim 100 \mathrm{~nm}$. These nanoparticles were located in the cytoplasm and in the nucleus of the cells. The dimensions of these particles were smaller in nucleus compared to the cytoplasmic particles $(33,34)$.

\section{MECHANISM OF NANOPARTICLE FORMATION}

In producing nanoparticles using the intracellular and an extracellular extract of organisms, the extract is simply mixed with a solution of the metal salt at room temperature. The reaction is complete within minutes. Nanoparticles of silver, gold and other metals have been produced previously (35). Fig. 1 shows a picture of various organisms used for 


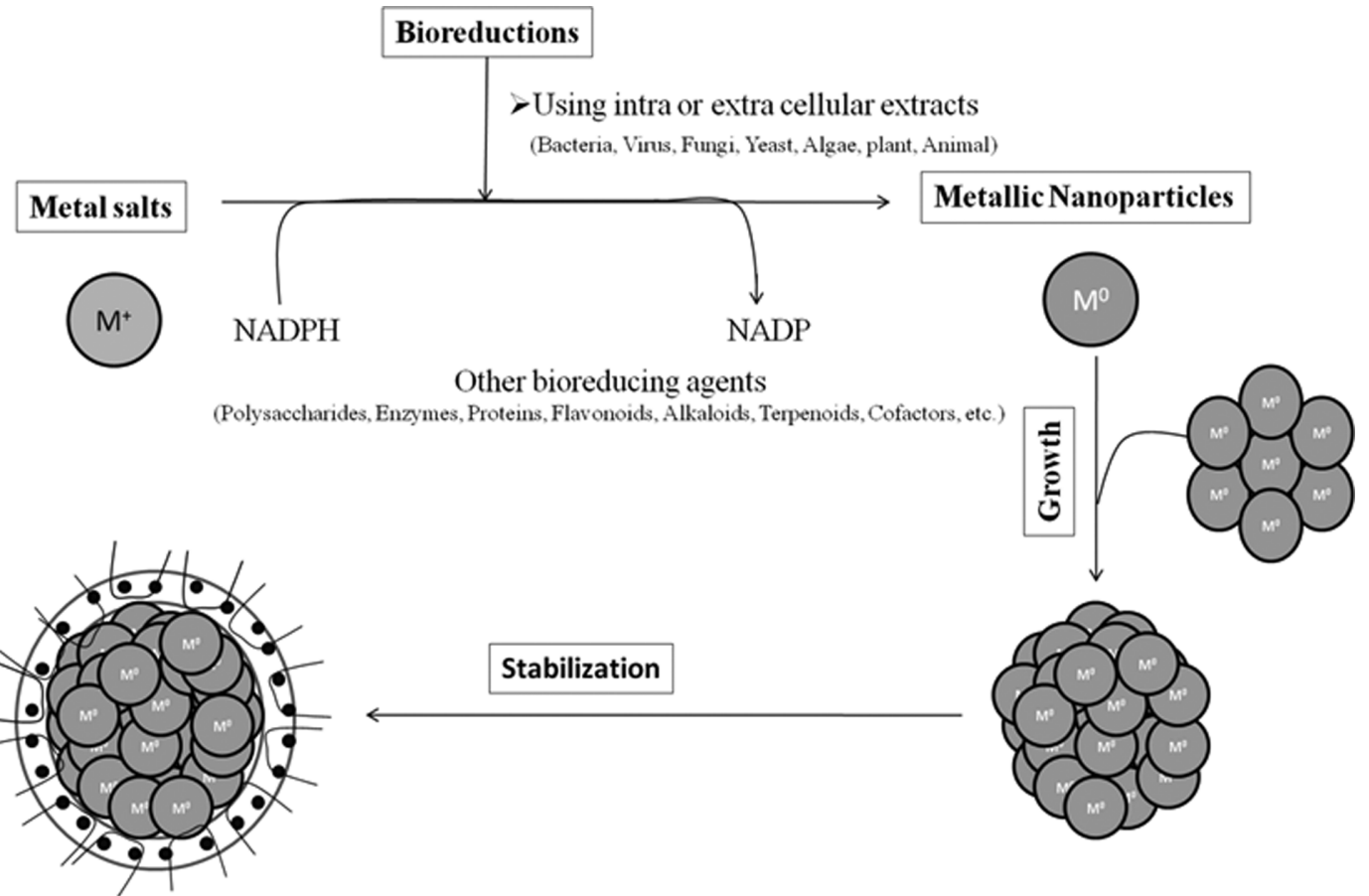

Fig. 1. Mechanisms of nanoparticle synthesis.

the biosynthesis of nanoparticles. The nature of the living extract, its concentration, the concentration of the metal salt, the $\mathrm{pH}$, temperature and contact time are known to affect the rate of production of the nanoparticles, their quantity and other characteristics.

\section{APPLICATIONS OF METAL NANOPARTICLES IN ANTIBACTERIAL ACTIVITY}

Mahendra et al. (36) reported that the silver nanoparticles show efficient antimicrobial property due to their extremely large surface area, which provides better contact with microorganisms. The nanoparticles penetrate the cell membrane or attached to the surface of the bacteria based on the size. Shekar et al. (37) reported that all AgNPs were found to be highly toxic to the bacterial strains and their antibacterial efficacy increased by lowering particle size. This effect was significantly enhanced as the size of nanoparticles approached the sub- $10 \mathrm{~nm}$ range and, $5 \mathrm{~nm}$ AgNPs demonstrated the fastest bactericidal activity as compared to $7 \mathrm{~nm}$ and $10 \mathrm{~nm}$ AgNPs at their respective, Minimimum bactericidal concentration. The bacterial membrane contains sulfur-containing proteins and the silver nanoparticles interact with these proteins in the cell as well as with the phosphorus containing compounds like DNA. Silver has a greater affinity to bind with sulphur and phosphorus containing bio-molecules of the cell. Therefore, sulphur containing proteins in the cell membrane, inside the cells and phosphorus containing elements like DNA is likely to be the preferred sites for bind- ing of silver nanoparticles (38). If the silver nanoparticles enter the bacterial cell it forms a low molecular weight region in the center of the bacteria to which the bacteria conglomerates thus, protecting the DNA from the silver ions. The nanoparticles preferably attack the respiratory chain, cell division finally leading to cell death. The nanoparticles release

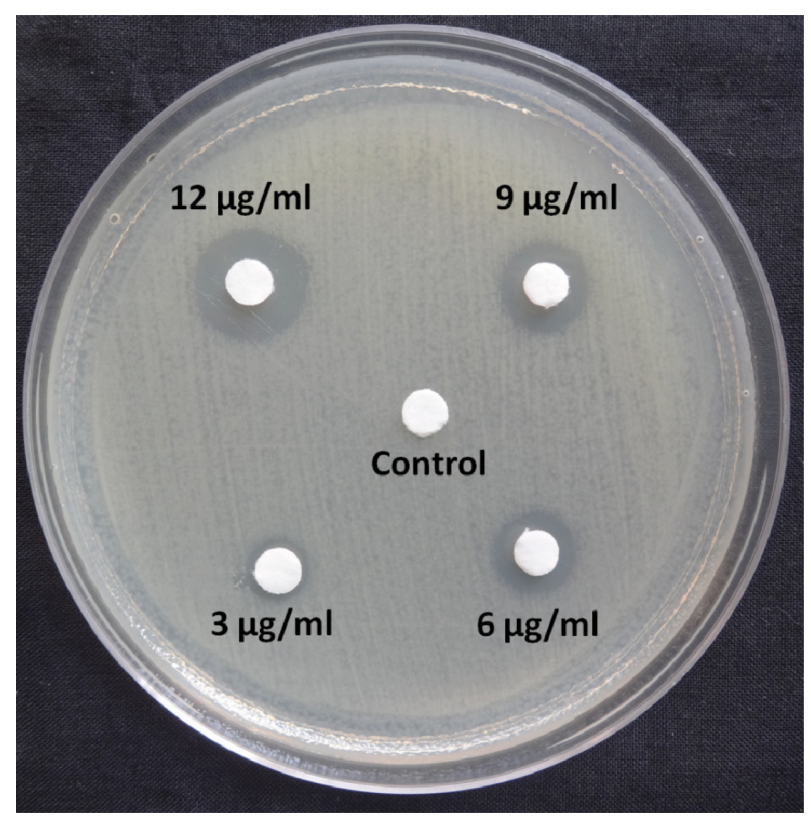

Fig. 2. Disc diffusion test on Muller Hinton agar medium using AgNPs against $E$. coli. 


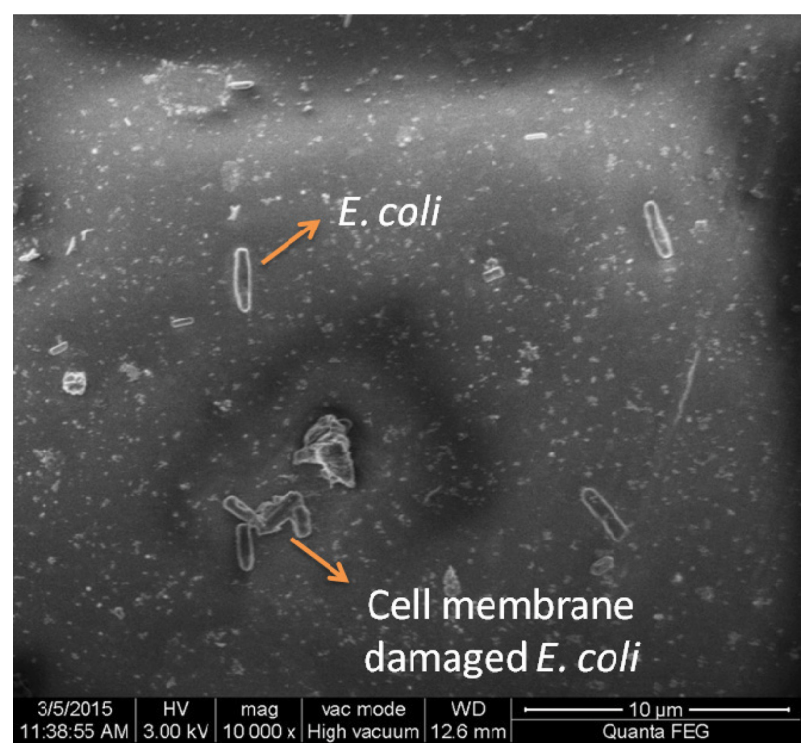

Fig. 3. FE-SEM images of $E$. coli treated with AgNPs $(6 \mu \mathrm{g} / \mathrm{mL})$.

silver ions in the bacterial cells, which enhance their bactericidal activity (38-42).

In the present study, we investigated whether these nanoparticles could induce nucleic acid DNA damage. For the assay of DNA damage, agarose gel electrophoresis was performed as per the manufacturer's instructions using a commercially available DNA extraction kit (Bangalore Genei ${ }^{\mathrm{TM}}$, Bengaluru, India). The disc agar diffusion method was carried out to find the minimum inhibitory concentration of the AgNPs. Fig. 2 illustrates that $3 \mu \mathrm{g} / \mathrm{mL}$ shows the zone of inhibition around $7 \mathrm{~mm}$ including the disc $(6 \mathrm{~mm}) .6 \mu \mathrm{g} / \mathrm{mL}$ which shows a little bigger zone of inhibition around $9 \mathrm{~mm}$ including the disc and this was taken for further analysis with field emission scanning electron microscopy (FESEM). Fig. 3 shows the FE-SEM images of the treated $E$. coli with the AgNPs. The morphological changes of E. coli was observed after the treatment with the $6 \mu \mathrm{g} / \mathrm{mL} \mathrm{AgNPs..}$ The rupture of cell membrane leading to bacterial cell death is clearly shown.

The bacterial cells of Gram negative, E. coli was harvested (before and after treatment with $6 \mu \mathrm{g} / \mathrm{mL}$ of AgNPs) by centrifugation at $8000 \mathrm{rpm}$ for $10 \mathrm{~min}$. The extracted DNA was analyzed for the occurrence of DNA damage. Surprisingly, $4 \mathrm{hr}$ treated cells of $E$. coli showed remarkable DNA damage. However, the DNA of untreated cells remained intact shown in Fig. 4. It was observed that the amount of DNA damage within the cells increased with an increasing concentration of the AgNPs, and the damage to DNA from $E$. coli was higher than that Gram positive from $B$. subtilis, implying that E. coli may suffer greater membrane damage than $B$. subtilis. The various mechanisms by which silver ions were thought to act includes structural changes in the cell wall of bacteria, interactions with thiol

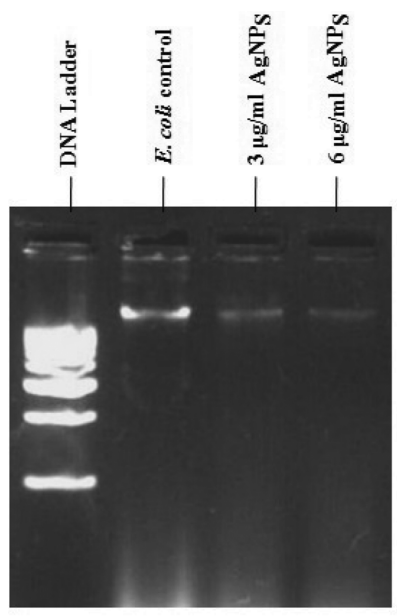

(A)

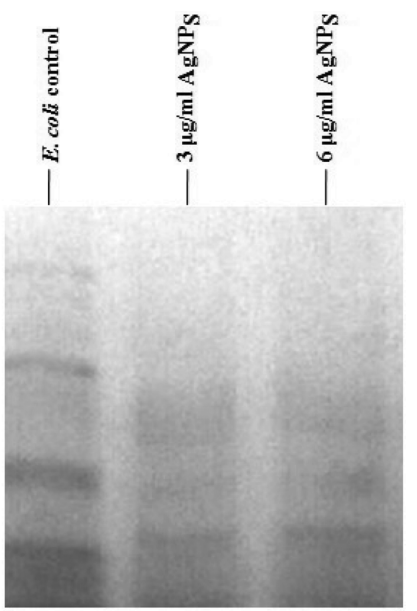

(B)
Fig. 4. (A) Agarose gel electrophoresis of E. coli control and treated cells for DNA Analysis, (B) SDS-PAGE Protein analysis of E. coli cells after treatment with AgNPs.

groups in proteins and enzymes, and interruption of DNA replication due to damage of the DNA (43). Previously, Ramamurthy et al. (44) studied the effect of silver nanoparticles on $E$. coli, silver nanoparticles penetrate the nucleic acid DNA of $E$. coli and exhibit antibacterial effect by causing DNA damage at low concentrations. Specific DNA smearing is a characteristic feature of cell death.

In agreement with the DNA damage, the amount of protein present in the cell suspension of the E. coli strain was analyzed by $12 \%$ SDS-PAGE. It was observed that for $E$. coli treated with AgNPs showed protein bands were missing when compared with the control. With the increase in the concentration of AgNPs, there was a further decrease in the protein band intensity shown in Fig. 4. The effect was more pronounced in case of E. coli bacteria than B. subtilis bacteria. Several reports propose that the affinity of AgNPs to the thiol groups of the proteins cause unfolding of the protein chain. This might result in the degradation of the proteins. Moreover the AgNPs are also implicated in the inhibition of the translational process by inhibiting various translation factors and hence preventing protein synthesis.

\section{CONCLUSIONS}

In recent years, there is an increased interest in studying the novel metal nanoparticles. In particular, biological nanoparticles have been reported to produce various sources possessing as an antibacterial activity. Increasing awareness towards green chemistry and biological processes has led to a desire to develop an environment-friendly approach for the synthesis of non-toxic nanoparticles. Unlike other processes such as physical and chemical methods, which involve hazardous chemicals. Biosynthesis of nanoparticles 
is cost-effective and eco-friendly approach. Therefore, biosynthesis of nanoparticles has been emerged as an important branch of nanobiotechnology. Due to their rich diversity, microorganisms have the innate potential for the synthesis of nanoparticles and they could be regarded as potential biofactories for nanoparticles synthesis. However, to improve the rate of synthesis and monodispersity of nanoparticles, factors such as microbial cultivation methods and downstream processing techniques have to be improved. Further, the combinatorial approach such as photobiological methods may be used. For instance, a great deal of effort has been put into the biosynthesis of nanoparticles, especially metal nanoparticles using plants. The use of plants and plant products as sustainable and renewable resources in the synthesis of nanoparticles is more advantageous over prokaryotic microbes, which need expensive methodologies for maintaining microbial cultures and downstream processing. Furthermore, the biosynthesized nanoparticle was explained the role of silver nanoparticles in antibacterial application against Gram negative bacterial strain E. coli.

\section{ACKNOWLEDGMENTS}

The author is acknowledging to the SRM University for providing the necessary chemicals and facilities to carry out this work.

\section{REFERENCES}

1. Bhattacharya, R. and Mukherjee, P. (2008) Biological properties of "naked" metal nanoparticles. Adv. Drug Deliv. Rev., 60, 1289-1306.

2. Bar, H., Bhui, D.K., Sahoo, G.P., Sarkar, P., De, S.P. and Misra, A. (2009) Green synthesis of silver nanoparticles using latex of Jatropha curcas. Colloids Surf., A, 339, 134-139.

3. Das, J. and Velusamy, P. (2014) Catalytic reduction of methylene blue using biogenic gold nanoparticles from Sesbania grandiflora L. J. Taiwan Inst. Chem. Eng., 45, 2280-2285.

4. Narayanan, K.B. and Sakthivel, N. (2010) Biological synthesis of metal nanoparticles by microbes. Adv. Colloid Interface Sci., 156, 1-13.

5. Wei, D. and Qian, W. (2008) Facile synthesis of Ag and Au nanoparticles utilizing chitosan as a mediator agent. Colloids Surf. B Biointerfaces, 62, 136-142.

6. Li, X., Xu, H., Chen, Z. and Chen, G. (2011) Biosynthesis of nanoparticles by microorganisms and their applications. $J$. Nanomater., 2011, 270974.

7. Dadosh, T. (2009) Synthesis of uniform silver nanoparticles with a controllable size. Mater. Lett., 63, 2236-2238.

8. Shakeel, A., Mudasir, A., Babu, L.S. and Saiqa, I. (2015) A review on plants extract mediated synthesis of silver nanoparticles for antimicrobial applications: A green expertise. $J . A d v$. Res., Doi:10.1016/J.Jare.2015.02.007.

9. Husseiney, M.I., El-Aziz, M.A., Badr, Y. and Mahmoud, M.A. (2007) Biosynthesis of gold nanoparticles using Pseudomonas aeruginosa. Spectrochim. Acta A, 67, 1003-1006.
10. Priyadarshini, S., Gopinath, V., Meera Priyadharsshini, N., Mubarakali, D. and Velusamy, P. (2013) Synthesis of anisotropic silver nanoparticles using novel strain, Bacillus flexus and its biomedical application. Colloids Surf. B Biointerfaces, 102, 232-237.

11. Klaus, T., Joerger, R., Olsson, E. and Granqvist, C.G. (1999) Silver-based crystalline nanoparticles, microbially fabricated. Proc. Natl. Acad. Sci. U.S.A., 96, 13611-13614.

12. Reddy, A.S., Chen, C.Y., Chen, C.C., Jean, J.S., Chen, H.R., Tseng, M.J., Fan, C.W. and Wang, J.C. (2010) Biological synthesis of gold and silver nanoparticles mediated by the bacteria Bacillus subtilis. J. Nanosci. Nanotechnol., 10, 6567-6574.

13. Wei, X., Luo, M., Li, W., Yang, L., Liang, X., Xu, L., Kong, P. and Liu, H. (2012) Synthesis of silver nanoparticles by solar irradiation of cell-free Bacillus amyloliquefaciens extracts and $\mathrm{AgNO}_{3}$. Bioresour. Technol., 103, 273-278.

14. Liu, L., Cañizares, M.C., Monger, W., Perrin, Y., Tsakiris, E., Porta, C., Shariat, N., Nicholson, L. and Lomonossoff, G.P. (2005) Cowpea mosaic virus-based systems for the production of antigens and antibodies in plants. Vaccine, 23, 17881792.

15. Blum, A.S., Soto, C.M., Wilson, C.D., Brower, T.L., Pollack, S.K., Schull, T.L., Chatterji, A., Lin, T., Johnson, J.E., Amsinck, C., Franzon, P., Shashidhar, R. and Ratna, B.R. (2005) An engineered virus as a scaffold for three-dimensional selfassembly on the nanoscale. Small, 1, 702-706.

16. Yu, L., Banerjee, I.A. and Matsui, H. (2003) Direct growth of shape-controlled nanocrystals on nanotubes via biological recognition. J. Am. Chem. Soc., 125, 14837-14840.

17. Marshall, M., Beliaev, A., Dohnalkova, A., David, W., Shi, L. and Wang, Z. (2007) C-Type cytochrome-dependent formation of U(IV) nanoparticles by Shewanella oneidensis. Plos Biol., 4, 1324-1333.

18. Lee, S.W., Mao, C., Flynn, C.E. and Belcher, A.M. (2002) Ordering of quantum dots, using genetically engineered viruses. Science, 296, 892-895.

19. Dias, M.A., Lacerda, I.C., Pimentel, P.F., de Castro, H.F. and Rosa, C.A. (2002) Removal of heavy metals by an Aspergillus terreus strain immobilized in a polyurethane matrix. Lett. Appl. Microbiol., 34, 46-50.

20. Vigneshwaran, N., Ashtaputre, N.M., Varadarajan, P.V., Nachane, R.P., Paralikar, K.M. and Balasubramanya, R.H. (2007) Biological synthesis of silver nanoparticles using the fungus Aspergillus flavus. Mater. Lett., 61, 1413-1418.

21. Mariekie, G. and Anthony, P. (2006) Microbial production of gold nanoparticles. Gold Bull., 39, 22-28.

22. Shenton, W., Douglas, T., Young, M., Stubbs, G. and Mann, S. (1999) Inorganic-organic nanotube composites from template mineralization of tobacco mosaic virus. Adv. Mater., 11, 253256.

23. Mao, C., Flynn, C.E., Hayhurst, A., Sweeney, R., Qi, J., Georgiou, G., Iverson, B. and Belcher, A.M. (2003) Viral assembly of oriented quantum dot nanowires. Proc. Natl. Acad. Sci. U.S.A., 100, 6946-6951.

24. Kowshik, M., Deshmukh, N., Vogel, W., Urban, J., Kulkarni, S.K. and Paknikar, K.M. (2002) Microbial synthesis of semiconductor Cds nanoparticles, their characterization, and their use in the fabrication of an ideal diode. Biotechnol. Bioeng., 78, $583-588$. 
25. Awadalla, F.T. and Pesic, B. (1992) Biosorption of cobalt with the AMTTM metal removing agent. Hydrometallurgy, 28, 6580.

26. Gardea-Torresdey, J.L., Gomez, E., Peralta-Videa, J.R., Parsons, J.G., Troiani, H. and Jose-Yacaman, M. (2003) Alfalfa sprouts: A natural source for the synthesis of silver nanoparticles. Langmuir, 19, 1357-1361.

27. Hosea, M., Greene, B., Mcpherson, R., Henzl, M., Alexander, M.D. and Darnall, D.W. (1986) Accumulation of elemental gold on the alga Chlorella vulgaris. Inorg. Chim. Acta, 123, 161-165.

28. Xie, J., Lee, J.Y., Wang, D.I. and Ting, Y.P. (2007) Identification of active biomolecules in the high-yield synthesis of single-crystalline gold nanoplates in algal solutions. Small, 3, 672-682.

29. Mata, Y.N., Blázquez, M.L., Ballester, A., González, F. and Muñoz, J.A. (2008) Characterization of the biosorption of cadmium, lead and copper with the brown algae Fucus vesiculosus. J. Hazard. Mater., 158, 316-323.

30. Das, J. and Velusamy, P. (2013) Antibacterial effects of biosynthesized silver nanoparticles using aqueous leaf extract of Rosmarinus officinalis L. Mater. Res. Bull., 48, 4531-4537.

31. Das, J., Das, M.P. and Velusamy, P. (2013) Sesbania grandiflora leaf extract mediated green synthesis of antibacterial silver nanoparticles against selected human pathogens. Spectrochim. Acta, Part A, 104, 265-270.

32. Gopinath, V., Mubarakali, D., Priyadarshini, S., Meera, P.N., Noor, T. and Velusamy, P. (2012) Biosynthesis of silver nanoparticles from Tribulus terrestris and its antimicrobial activity: A novel biological approach. Colloids Surf. B Biointerfaces, 96, 69-74.

33. Anshup, A., Venkataraman, J.S., Subramaniam, C., Kumar, R.R., Priya, S., Kumar, T.R., Omkumar, R.V., John, A. and Pradeep, T. (2005) Growth of gold nanoparticles in human cells. Langmuir, 21, 11562-11567.

34. Larios-Rodriguez, E., Rangel-Ayon, C., Castillo, S.J., Zavala, G. and Herrera-Urbina, R. (2011) Bio-synthesis of gold nanoparticles by human epithelial cells, in vivo. Nanotechnol- ogy, 22, 355601

35. Dwivedi, A.D. and Gopal, K. (2010) Biosynthesis of silver and gold nanoparticles using chenopodium album leaf extract. Colloids Surf., A, 369, 27-33.

36. Rai, M., Yadav, A. and Gade, A. (2009) Silver nanoparticles as a new generation of antimicrobials. Biotechnol. Adv., 27, 76-83.

37. Agnihotri, S., Mukherji, S. and Mukherji, S. (2014) Size-controlled silver nanoparticles synthesized over the range 5-100 $\mathrm{Nm}$ using the same protocol and their antibacterial efficacy. RSC Adv., 4, 3974-3983.

38. Park, Y. (2014) A New Paradigm shift for the green synthesis of antibacterial silver nanoparticles utilizing plant extracts. Toxicol. Res., 30, 169-178.

39. Feng, Q.L., Wu, J., Chen, G.Q., Cui, F.Z., Kim, T.N. and Kim, J.O. (2000) A mechanistic study of the antibacterial effect of silver ions on Escherichia coli and Staphylococcus aureus. J. Biomed. Mater. Res., 52, 662-668.

40. Sondi, I. and Salopek-Sondi, B. (2007) Silver nanoparticles as antimicrobial agent: A case study on E. coli as a model for gram-negative bacteria. J. Colloid Interface Sci., 275, 177182.

41. Morones, J.R., Elechiguerra, J.L., Camacho, A., Holt, K., Kouri, J.B., Ramírez, J.T. and Yacaman, M.J. (2005) The bactericidal effect of silver nanoparticles. Nanotechnology, 16, 2346-2353.

42. Song, H.Y., Ko, K.K., Oh, L.H. and Lee, B.T. (2006) Fabrication of silver nanoparticles and their antimicrobial mechanisms. Eur. Cell. Mater., 11, 58.

43. Mohanpuria, P., Rana, N.K. and Yadav, S.K. (2008) Biosynthesis of nanoparticles: Technological concepts and future applications. J. Nanopart. Res., 10, 507-517.

44. Ramamurthy, C.H., Padma, M., Samadanam, I.D., Mareeswaran, R., Suyavaran, A., Kumar, M.S., Premkumar, K. and Thirunavukkarasu, C. (2013) The extra cellular synthesis of gold and silver nanoparticles and their free radical scavenging and antibacterial properties. Colloids Surf. B Biointerfaces, 102, 808-815. 